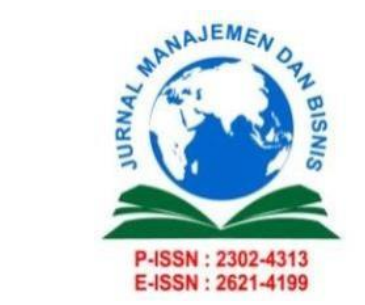

\author{
Jurnal Manajemen dan Bisnis \\ Vol. 10, No. 2, December 2021, pp. 30-40

\section{Sekolah Tinggi Ilmu Ekonomi Indragiri (STIE-I) Rengat}

https://journal.stieindragiri.ac.id/index.php/jmbi/issue/view/20

\title{
MSME COMPETITIVE ADVANTAGES REVIEWED FROM ENTREPRENEURSHIP INSIGHT AND MARKET ORIENTATION ASPECTS WITH INNOVATION AS A MEDIUM
}

\author{
Julyanthry $^{1)}$, Debi Eka Putri ${ }^{2)}$, Darwin Lie ${ }^{3)}$, Acai Sudirman ${ }^{4)}$ \\ 1) 2) 3) 4) Management Study Program, Sekolah Tinggi Ilmu Ekonomi Sultan Agung \\ julyanthry@stiesultanagung.ac.id ${ }^{1)}$,debiekaputri@stiesultanagung.ac.id ${ }^{2)}{\text { darwin @ stiesultanagung.ac.id }{ }^{3)}}^{3}$ \\ ,acaivenly@stiesultanagung.ac.id ${ }^{4}$ \\ Submited: 2021.10.06 Reviewed: 2021.11.20 Accepted: 2021.12.31 \\ https://doi.org/10.34006/jmbi.v10i2.306
}

\begin{abstract}
Innovation and creativity in this digital era are needed in developing the business you want to do so that you don't get stuck in daily operational activities and pursue performance targets. Therefore, it takes a solid entrepreneurial spirit from within business actors to create innovation and creativity. In addition, the role of market orientation also plays a major role in providing broad market access so that the product innovations developed can reach end users. Thus, it is hoped that every business undertaken by business actors can survive and increase their competitive advantage. The urgency of this research is to examine the effect of entrepreneurship insight and market orientation on innovation and competitive advantage. On the other hand, This study also tries to confirm the mediating effect of innovation on the impact of entrepreneurship insight and market orientation on competitive advantage. This study uses a causal quantitative research design. The number of samples used in this study were 170 MSME business actors. The data analysis method used is Partial Least Square (PLS). The data analysis test tool uses statistical software Smartpls 3.0. This study concludes that the effect of entrepreneurship insight and market orientation on innovation is positive and significant. Likewise, the influence of entrepreneurship insight and innovation on competitive advantage obtained positive and significant results. On the other hand, the effect of market orientation on competitive advantage obtained positive but not significant results. This study also confirms that innovation can mediate the relationship between entrepreneurial insight and market orientation to competitive advantage.
\end{abstract}

Keywords: Entrepreneurship Insight, Market Orientation, Innovation, Competitive Advantage

\section{INTRODUCTION}

The development of entrepreneurship is currently experiencing dynamics of change for the better with conditions reflected in government policies that have begun to pay attention to the needs of an entrepreneur in entrepreneurship. This condition reflects the level of government's role needed in developing entrepreneurial potential that can be done when someone wants to do entrepreneurship activities (Purnomo et al., 2020). An absolute requirement to win the competition in this modern era, all countries must have a competitive advantage (Anning-Dorson, 2018). Indonesia as a developing country, of course, does not only rely on big companies to drive the economy, but it needs the involvement of MSMEs in development and economic growth (Lestari et al., 2019). With the development of a business field, many similar businesses will appear. Therefore, each business actor has a different strategy in achieving competitive advantage, although there may be innovations in products, services, processes, programs, technology or organizational structures, the company's 
capabilities are needed to achieve product or service innovation to achieve competitive advantage (Limaj \& Bernroider, 2019).

Problems that are still crucially faced by MSMEs include the low entrepreneurial spirit of each business actor. This causes business actors to often experience barriers to innovation and creativity on marketed products (T. Lee \& Chu, 2011). The entrepreneurial spirit (entrepreneurship insight) needs to be possessed by MSMEs to encourage the spirit of innovation and the ability to take risks that support the success of a business in facing competition in the global order.(Santhi \& Affandi, 2020). Insight about entrepreneurship is the benchmark that distinguishes a business person from others, and this insight will also determine the direction of innovation that will be developed for his products and business both in the short and long term (Nurdin et al., 2020). Of course, this is crucial for business actors to consider for their entrepreneurial insight, because market orientation that can run optimally or not in supporting business processes depends on the level of entrepreneurial insight possessed by each business actor (Arzubiaga et al., 2018).

To compete in business competition and having an entrepreneurial spirit, of course, MSMEs must also depend on market orientation generated by using knowledge related to the market to be entered and including its characteristics (Kiki et al., 2020). Often business actors can create high product innovation, but cannot access the target market (Harjadi et al., 2020). This is due to the inability of business actors to read market opportunities and develop appropriate strategies when entering the market. In addition, another obstacle that business actors often face is the lack of understanding of market orientation, especially virtual-based market orientation or commonly called e-commerce. Business actors realize that to win the competition requires a broader understanding of the target market to be addressed (Udriyah et al., 2019). Often business actors fail due to delays in information about market access and the development of information about increasingly complex market changes. On the other hand, business actors have not realized that business startups can grow or create new opportunities that are willing to adapt and change the traditional market model to a virtual market.

Various other obstacles still often encountered in MSMEs are the low quality of human resources in innovating. Innovation and creativity in this digital era are needed to develop the business you want to do so as not to be trapped in daily operational activities and pursue performance targets (Purnomo et al., 2020). Innovation is a determining factor in industrial competition and is a formidable weapon against competition. The low innovation of the products produced is the main obstacle to marketing products to consumers. A business venture that can innovate, then the business can lead and minimize the possibility of competitors to innovate early (Lestari et al., 2019). One of the keys to increasing capacity and creating competitive advantage for SMEs is innovation.(Distanont \& Khongmalai, 2020), argues that innovation can create sustainable growth that leads to competitive advantage in internal and external markets. Therefore, business actors must prepare an innovation strategy to create an advantage over competitors (Aziz \& Samad, 2016).

The urgency of competitive advantage in business is seen when a business can survive in various contexts of changing internal and external environments. This is important to be studied further, considering that the role of competitive advantage has a big impact on business sustainability in the future. Therefore, it is important to know the fundamental factors that drive competitive advantage from the internal environment itself. Research result (J. Lee et al., 2019), concluded that it is crucial to increase the entrepreneurial spirit channeled in the form of metacognition through entrepreneurship education. This cannot be separated from the cultivation of entrepreneurship from the will to run a business. With a strong entrepreneurial spirit, it will have an impact on the power of sustainable innovation. On the other hand, creating and encouraging innovation requires a touch of market orientation to create customer value that is equal to or higher than the price. Study results (Meylananda et al., 2021), explains that business strategy in the form of market orientation has a significant influence on product creativity in the form of continuous innovation. In addition to the need for an entrepreneurial spirit and market orientation in encouraging innovation, business actors need to pay attention to competitive advantage as a weapon to win competition in the market. Studies conducted 
For MSMEs in Pematangsiantar City to become an economic driver, it is necessary to pay attention to the entrepreneurial spirit and market orientation through product innovation and a deeper understanding of market orientation and support for support a high entrepreneurial spirit. If MSMEs want to have a competitive advantage, of course, they must know about some market opportunities by adding existing innovations. The importance of an entrepreneurial spirit from an early age is the foundation for building and creating innovative products. In addition, understanding related to product innovation is used as an entrepreneurial footing to create a competitive market by taking into account contemporary market orientation. If entrepreneurship insight, market orientation, and innovation are combined and managed properly, this will create a competitive advantage for SMEs. The main purpose of this research is to analyze the competitive advantage of SMEs in terms of entrepreneurship insight and market orientation with innovation as a mediator. Then with this article, it is hoped that it can provide input in the form of recommendations from research results to local governments in making policies related to the competitiveness of MSMEs and other business units.

\section{FRAMEWORK}

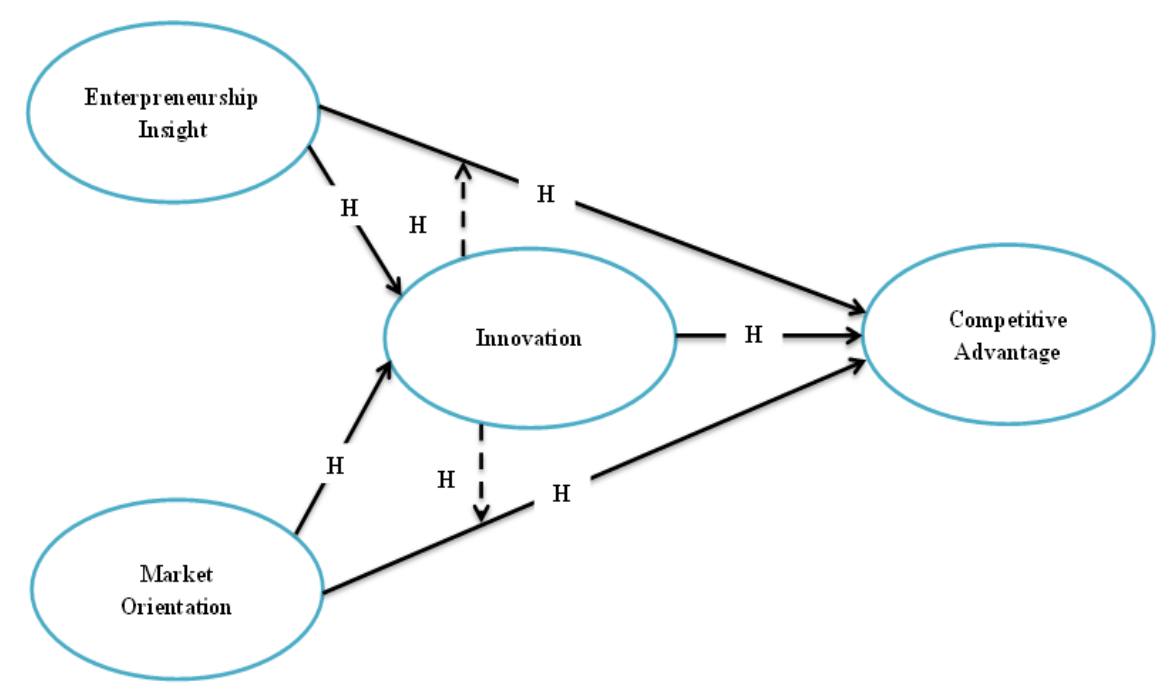

Figure 1. Research Framework

\section{RESEARCH METHODOLOGY}

\section{RESEARCH SITES}

The research plan is carried out in early 2021 until the end of 2021. The selection of locations is adjusted to the number of MSMEs in each kelurahan in the sub-districts of East Siantar, West Siantar, North Siantar, South Siantar, Siantar Marihat, Siantar Martoba, Siantar Sitalasari, Siantar Marimbum .

\section{TYPES OF RESEARCH}

This study uses a literature and field research design with a causal quantitative approach.

\section{POPULATION AND SAMPLE}

The population in this study is the total number of SMEs in Pematangsiantar City. The sampling method used in this study is the convenience sampling method. This technique was chosen because it is the fastest method due to time constraints. Anyone who accidentally meets the researcher can be used as a sample if the person is considered suitable as a data source. According to (Hair, 2014), the number of samples can be determined from 5-10 times the number of indicators used in a single construct. This study uses 34 indicators from 12 existing dimensions, so the number of samples obtained is $34 \times 5=170$. 


\section{DATA ANALYSIS}

The data analysis method used is Partial Least Square (PLS). The data analysis test tool uses the statistical software Smartpls 3.0. The analysis stage consists of testing the validity and reliability, and evaluating the external model with convergent validity. The expected convergent validity criteria are > 0.7 (Hair, 2014). The internal evaluation model reviews the value of R Square (R2) with the criteria that the $\mathrm{R} 2$ value is in the range of $0.5-0.6$, which means good, $0-0.33$, which means moderate and 0-0.19, which means weak. Next, reviewing the F-Square (f2) value with assessment criteria of 0.02 which means weak, 0.15 which means moderate, and 0.35 which means large (Hair, 2014). Finally, testing the hypothesis which is the criteria for measuring significance and probability values $<0.05$.

\section{RESULTS AND DISCUSSION}

Table 1. Descriptions of Research Respondents

\begin{tabular}{|c|c|c|c|}
\hline Category & Details & Amount & Percentage \\
\hline Gender & $\begin{array}{c}\text { Men } \\
\text { woman }\end{array}$ & $\begin{array}{c}65 \\
105 \\
\end{array}$ & $\begin{array}{l}38.24 \% \\
61.76 \% \\
\end{array}$ \\
\hline age & $\begin{array}{l}20-29 \text { years } \\
30-39 \text { years } \\
40-49 \text { years } \\
50-59 \text { years }\end{array}$ & $\begin{array}{l}20 \\
40 \\
83 \\
27 \\
\end{array}$ & $\begin{array}{l}11.77 \% \\
23.53 \% \\
48.82 \% \\
15.88 \% \\
\end{array}$ \\
\hline Level of education & $\begin{array}{c}\text { high school } \\
\text { Bachelor } \\
\text { Masters } \\
\end{array}$ & $\begin{array}{c}121 \\
40 \\
9 \\
\end{array}$ & $\begin{array}{c}71.18 \% \\
23.53 \% \\
5.29 \% \\
\end{array}$ \\
\hline Type of business & $\begin{array}{c}\text { Culinary } \\
\text { Fashion } \\
\text { Automotive } \\
\text { Agribusiness } \\
\text { Tour \& Travel } \\
\text { Creative Products } \\
\text { Internet Technology Business } \\
\text { Beauty And Beauty Products Business } \\
\text { Event Organizer } \\
\text { Cleaning Service } \\
\text { Other Types of Business }\end{array}$ & $\begin{array}{c}40 \\
18 \\
11 \\
12 \\
9 \\
4 \\
16 \\
12 \\
10 \\
6 \\
32\end{array}$ & $\begin{array}{c}23.54 \% \\
10.59 \% \\
6.48 \% \\
7.05 \% \\
5.29 \% \\
2.35 \% \\
9.42 \% \\
7.06 \% \\
5.88 \% \\
3.52 \% \\
18.82 \%\end{array}$ \\
\hline
\end{tabular}

Source: Processed Data (2021)

\section{OUTER MODEL MEASUREMENT}

The data from the study questionnaire was processed using the SmartPLS version 3.2.9 program, which followed the processing instructions provided by (Juliandi, 2018). The validity test and the reliability test were used to evaluate the outer model. The loading factor and AVE value determine convergent validity tests if the loading factor is more than 0.7 and the AVE value is less than 0.5. (Hair, 2014). The model reliability test may be observed in the value of Cronbach's alpha and composite reliability (CR), which has a value greater than 0.7 , according to (Hair, 2014). The following is an explanation of the Outler model measurement, which is shown in Figure 2 and Table 2 below: 


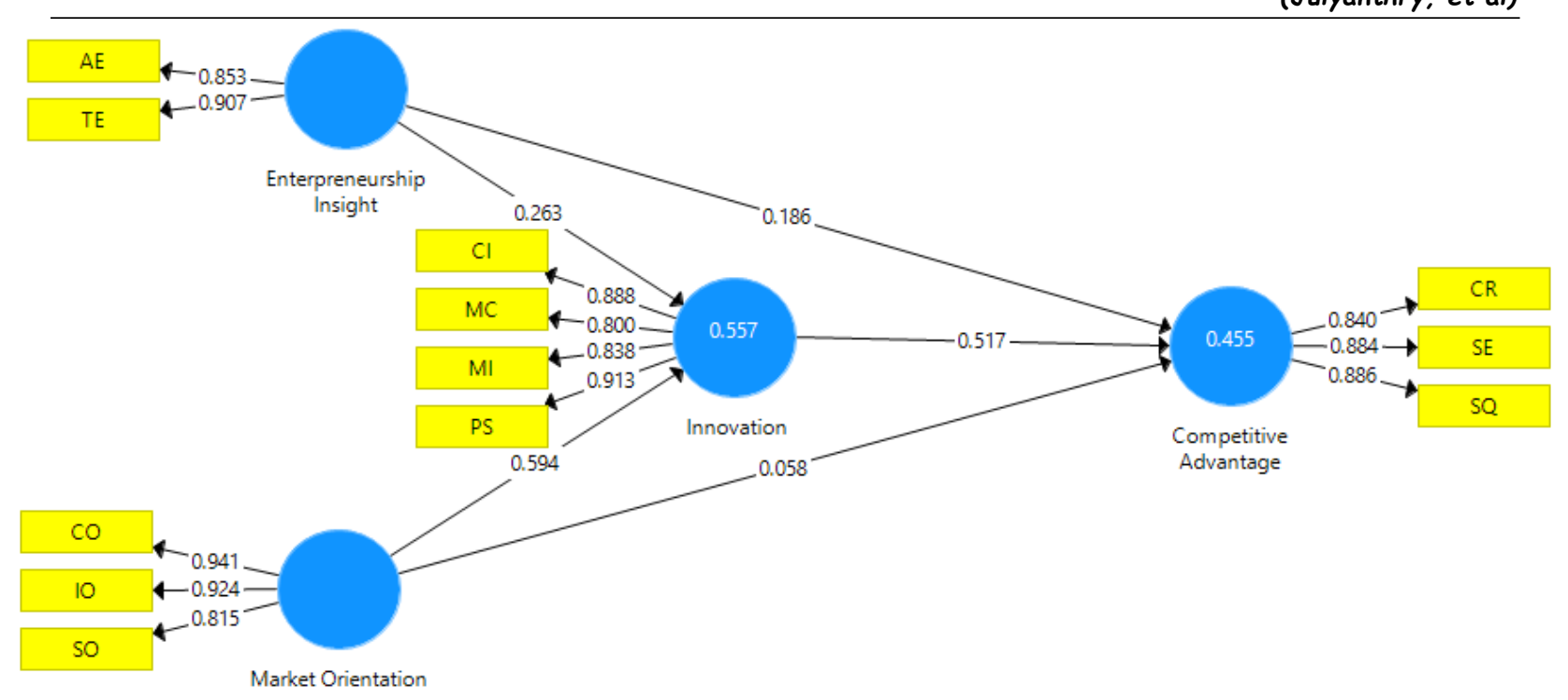

Figure 2.Outer Display Model

Table 2.Outer Model Measurement Results

\begin{tabular}{|c|c|c|c|c|c|}
\hline Construct/item & Code & Outler Loadings & Cronbach's alpha & $\mathbf{C R}$ & AVE \\
\hline \multicolumn{2}{|l|}{ Entrepreneurship Insight } & & 0.714 & 0.874 & 0.776 \\
\hline Transactional Entrepreneurship & $\mathrm{AE}$ & 0.853 & & & \\
\hline Authentic Entrepreneurship & TE & 0.907 & & & \\
\hline \multicolumn{2}{|l|}{ Market Orientation } & & 0.873 & 0.923 & 0.801 \\
\hline Customer Orientation & $\mathrm{CO}$ & 0.941 & & & \\
\hline Supplier Orientation & SO & 0.815 & & & \\
\hline Industrial Orientation & $\mathrm{IO}$ & 0.924 & & & \\
\hline \multicolumn{2}{|l|}{ Innovation } & & 0.883 & 0.920 & 0.42 \\
\hline Marketing Channels & $\mathrm{MC}$ & 0.800 & & & \\
\hline Marketing Innovation & MI & 0.838 & & & \\
\hline Product Segmentation & PS & 0.913 & & & \\
\hline Customer Insights & $\mathrm{CI}$ & 0.888 & & & \\
\hline \multicolumn{2}{|l|}{ Competitive Advantage } & & 0.840 & 0.904 & 0.758 \\
\hline Superior Efficiency & SE & 0.884 & & & \\
\hline Superior Quality & SQ & 0.886 & & & \\
\hline Customer Responsibility & $\mathrm{CR}$ & 0.840 & & & \\
\hline
\end{tabular}

Source: Processed Data (2021)

The value of each loading factor on the indicators of entrepreneurial insight, market orientation, innovation, and competitive advantage was found to be above 0.7 and above 0.5 for the average variance extracted ( AVE) values in the validity test given in Table 2 above. Furthermore, each variable's Cronbach's alpha value and composite reliability were both greater than 0.7 , indicating that all study variables had high reliability. These excellent values may be used to determine if the condition of the connection between variables is likewise good, allowing for additional testing.

\section{INNER MODEL MEASUREMENT}

SmartPLS 3.2.9 was used to bootstrap research data and assess the inner model. Bootstrapping yielded two results: the first was the importance of the two linked variables, as well as the study's Rsquare. The R-square value indicates the capacity of exogenous factors to construct endogenous variables. According to Chin et al., (2008), R-square values fall into three categories: weak, moderate, and strong. If the R-square value is 0.19 , the relationship between exogenous variables forming endogenous variables is weak; if it is 0.33 , the relationship is moderate; and if it is 0.67 , the relationship is strong. Meanwhile, according to (Sarwono, 2016), the connection between endogenous and exogenous variables is extremely strong if the R-square value is more than 0.67 . 
Table 3.Calculation results of the R-Square value

\begin{tabular}{|c|c|c|}
\hline Notes & $R$ Square & $R$ Square Adjusted \\
\hline Innovation & 0.557 & 0.552 \\
\hline Competitive Advantage & 0.455 & 0.446 \\
\hline
\end{tabular}

Source: Processed Data (2021)

According to the R-square value for the endogenous innovation variable, which is 0.558 , and the teacher performance endogenous variable, which is 0.455 and has a value range of $0.33-0.67$, the exogenous variable's overall capacity to explain the endogenous variable is modest. A significance test was also performed to establish the connection between exogenous and endogenous factors in order to verify hypothesis testing. The p-value reveals the significant criteria. If the p-value between the exogenous and endogenous variables is less than 0.05 with a significance level of $5 \%$, it means that the exogenous variable has a significant effect on the endogenous variable; on the other hand, if the value is greater than 0,05 , it means that the exogenous variable has no significant effect on the endogenous variable. The following are the hypothesis testing findings, which are described in Figure 3 and Table 4:

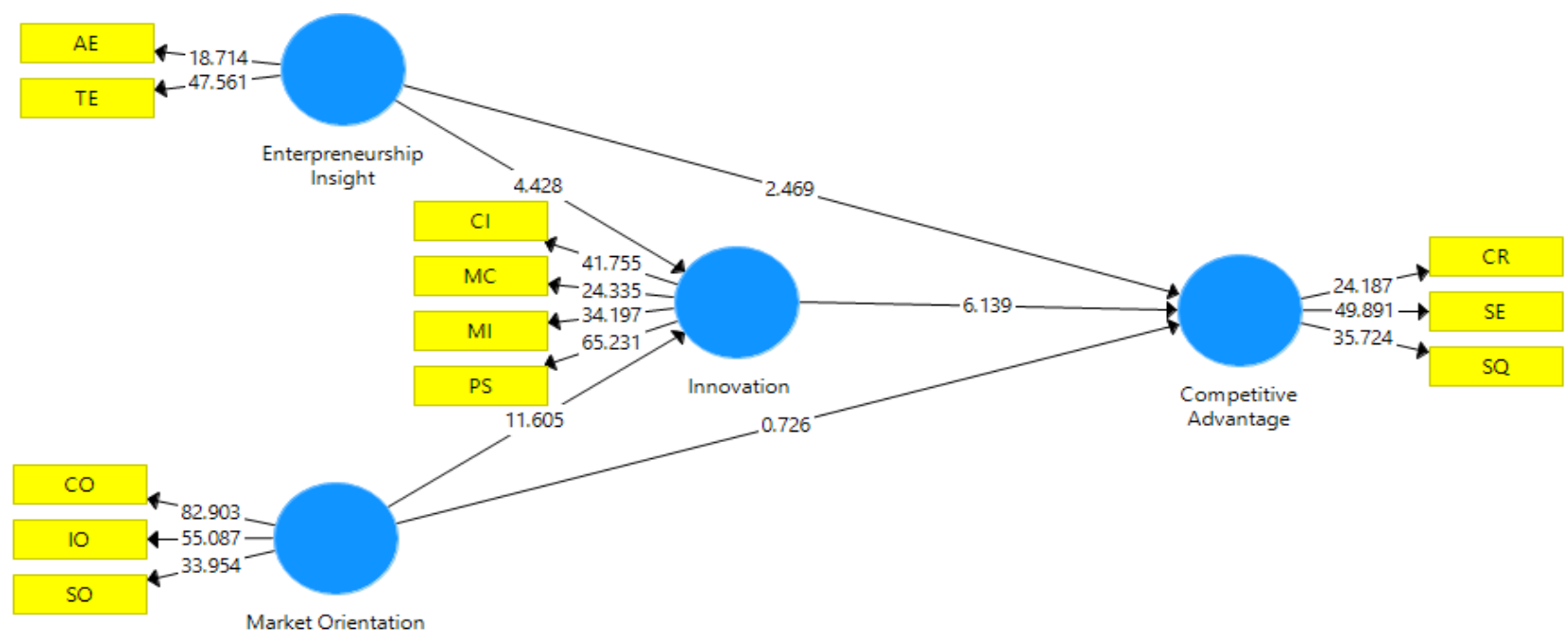

Figure 3.Inner Model Display

Table 4.Hypothesis Test Results

\begin{tabular}{|c|c|c|c|c|}
\hline Hypothesis & Coefficient & t-count & P-Value & Conclusion \\
\hline Entrepreneurship Insight > Innovation & 0.263 & 4.428 & $\mathbf{0 . 0 0 0}$ & Accepted \\
\hline Market Orientation >> Innovation & 0.594 & 11,605 & $\mathbf{0 . 0 0 0}$ & Accepted \\
\hline Entrepreneurship Insight >> Competitive Advantage & 0.186 & 2.469 & $\mathbf{0 . 0 1 4}$ & Accepted \\
\hline Market Orientation >> Competitive Advantage & 0.058 & 0.726 & $\mathbf{0 . 4 6 8}$ & Rejected \\
\hline Innovation >> Competitive Advantage & 0.517 & 6.139 & $\mathbf{0 . 0 0 0}$ & Accepted \\
\hline
\end{tabular}

Source: Processed Data (2021)

Based on the results of the processed data presented in table 4, it is known that the effect of entrepreneurship insight on innovation is positive and significant with the acquisition of a p-value of 0.000 , which is below 0.05 . Furthermore, the influence of market orientation on innovation obtained positive and significant results with a p-value of 0.000 , which is below 0.05 . Likewise, for the effect of entrepreneurship insight on competitive advantage, positive and significant results were obtained with a p-value of 0.014 , which was below 0.05 . On the other hand, positive but insignificant results were obtained for the effect of market orientation on competitive advantage, as evidenced by the acquisition of a p-value of 0.468 , which is above 0.05 . Then for the effect of innovation on competitive advantage, positive and significant results were obtained with a p-value of 0.000 , which is below 0.05 . Overall, from the 5 hypotheses built to test the direct effect between variables, it was 
concluded that 4 hypotheses were accepted and 1 hypothesis was declared rejected. Furthermore, to determine the mediating effect of employee engagement on the relationship between self-efficacy and organizational justice on employee performance, a mediation test was conducted using an indirect effect approach, with the explanation of the results as follows: Of the 5 hypotheses that were built to test the direct effect between variables, it was concluded that 4 hypotheses were accepted and 1 hypothesis was rejected. Furthermore, to find out the mediating effect of employee engagement on the relationship between self-efficacy and organizational justice on employee performance, a mediation test was conducted using an indirect effect approach, with the explanation of the results as follows: Of the 5 hypotheses that were built to test the direct effect between variables, it was concluded that 4 hypotheses were accepted and 1 hypothesis was rejected. Furthermore, to determine the mediating effect of employee engagement on the relationship between self-efficacy and organizational justice on employee performance, a mediation test was conducted using an indirect effect approach, with the explanation of the results as follows:

\section{Table 5. Mediation Test Results Based on Indirect Effect}

\begin{tabular}{|l|c|c|c|c|}
\hline Effect Between Variables & Coefficient & tcount & $\boldsymbol{P}$-Value & Conclusion \\
\hline Entrepreneurship Insight $>>$ Innovation $>$ Competitive Advantage & 0.136 & 3.052 & $\mathbf{0 . 0 0 2}$ & Accepted \\
\hline Market Orientation $>>$ Innovation $>>$ Competitive Advantage & 0.307 & 5.583 & $\mathbf{0 . 0 0 0}$ & Accepted \\
\hline
\end{tabular}

Source: processed data (2021)

Based on the processed data presented in table 5 above, it can be concluded that the innovation variable can mediate the relationship between entrepreneurship insight and competitive advantage, as evidenced by the acquisition of a p-value of 0.002 , which is below 0.05 . Furthermore, the innovation variable can mediate the relationship between market orientation and competitive advantage, as evidenced by acquiring a p-value of 0.000 , which is below 0.05 . So it can be concluded that the innovation variable has succeeded in being a mediating variable for the two direct relationships, namely the relationship between entrepreneurship insight and market orientation towards competitive advantage.

\section{DISCUSSION}

The research results developed through the first hypothesis, show that entrepreneurship insight has a positive and significant effect on innovation. These results prove that the role of entrepreneurial insight embedded in the mindset of business actors contributes to creativity through their creativity and innovation. The simple fact that a change in a person's mindset is very important to drive the key to success (Arzubiaga et al., 2018). The constant change of entrepreneurial insight is a business reality and business people must continue to adapt to the development of technology and information. Business actors who tend to have many ideas and have the key to their success are realizing these ideas and successfully growing them to fruition (Harvey et al., 2010). The implication of strong entrepreneurial insight will contribute to fostering high innovation power, so that business actors have a strong mentality to see risk as a challenge, not a negative thing (Setyanti et al., 2013). The research results developed through the second hypothesis, show that market orientation has a positive and significant effect on innovation. The role of market orientation as outlined through market research in developing product innovation is crucial to encourage competitive advantage in the long term. Through market research and market segmentation (Sultan et al., 2020). Then, business actors can develop the right marketing mix through renewable innovations for the products created. That way, the product can better meet customer requirements which in the end the product will win the competition in the market. Overall, incorporating product innovation based on market orientation helps ensure the business being run will not be left far behind by market competition (Yaskun \& Sudarmiatin, 2021). On the other hand, the urgency of market orientation can identify competition in each market line (Pratiwi \& Riana, 2021). it is certainly important to determine their profitability, competitive pressure and target competitive position.

The research results developed through the third hypothesis, show that entrepreneurship insight has a positive and significant effect on competitive advantage. These results confirm that the 
entrepreneurial spirit is very important to understand in its entirety, because the entrepreneurial spirit is not just a matter of trade and transactions, but entrepreneurship insight is a process of applying creativity and innovation based on interests and talents possessed (Bambang et al., 2021). In this case, every business actor must be creative and can see opportunities or patterns that apply in society. In entrepreneurship, of course, it takes a great intention which is the first step in starting entrepreneurship. Thus, a well-developed entrepreneurial insight will give creative ideas to create competitive business continuity (Zainol \& Al Mamun, 2018). The research results developed through the fourth hypothesis, show that market orientation has a positive but not significant effect on competitive advantage. These results confirm that the presence of market orientation affects the sustainable development of a business. Consumers want every business actor instead of selling as many products as possible that consumers don't want to buy. They conduct market research and develop an effective marketing mix for effective market orientation (Sutapa et al., 2017). Thus, product failures are much reduced as companies align their products with customer expectations and demands. The alignment of products following consumer expectations will encourage the development of business competitiveness to encourage long-term competitive advantage (Puspaningrum, 2017). The research results developed through the fifth hypothesis, show that innovation has a positive and significant effect on competitive advantage. Conducting business innovation is also one of the strategies to increase sales turnover in order to maintain the competitive advantage of a business. Creativity and innovation have an important role in running a business (Arsawan et al., 2020). The power of creativity should be based on advanced thinking, new ideas, and different from existing products. This maximizes creativity to give birth to an innovation, so the managed business will also appear different compared to other similar companies (Distanont \& Khongmalai, 2020).

The research results developed through the sixth hypothesis, show that innovation can mediate the relationship between entrepreneurship insight and competitive advantage. These results prove the role of innovation in closely related to entrepreneurial insight and competitive advantage. Business actors who have high entrepreneurial insight will try to understand product innovation as a refinement process to find out which products are successful and not. Keeping customers at the center of product innovation is today's core entrepreneurial focus (Sudirman et al., 2021). Taking a customer-centred approach allows every business actor to solve real customer problems by uncovering and incorporating preferences, habits, and buying behavior into every stage of the product development process. Suppose entrepreneurial insight is developed in conjunction with innovation (Afwa et al., 2021). In that case, this will develop product concepts that are in line with consumer needs and preferences and the implication will be to create a long-lasting competitive advantage in the market. The research results, which was developed through the seventh hypothesis, show that innovation can mediate the relationship between market orientation and competitive advantage. The results confirm that the role of innovation in the development of market orientation is crucial to achieve competitive advantage in the market. A business strategy that relies on market orientation based on consumer demand and subsequently includes product innovation will strengthen the product's position in the market (Djajasinga et al., 2021). This business strategy can encourage sales growth for these products because most consumers will judge these products to be quite competitive in market share (Fajrillah et al., 2020). In addition, if the implementation of market orientation goes well and is supported by qualified product innovation, it will be easier for business actors to achieve customer loyalty (Ayesha et al., 2021). Ultimately, the company will remain competitive for a long period.

\section{CONCLUSIONS AND SUGGESTIONS}

\section{CONCLUSION}

The study results conclude that from the 5 hypotheses developed to test the direct effect, 4 hypotheses are accepted and 1 hypothesis is rejected. The influence of entrepreneurship insight and market orientation on innovation obtained positive and significant results. Likewise, the influence of 
entrepreneurship insight and innovation on competitive advantage obtained positive and significant results. Optimizing aspects of entrepreneurship insight through proper risk taking and independence in running a business will create superior competitiveness in the long term. Furthermore, the ability to master business management information systems and optimal management of internal resources will impact superior competitiveness. In general, new product innovations that have never been on the market have received little attention, so entrepreneurs need to improve their innovations in a comprehensive and structured manner. Increase product variety, create unique and different products from competitors, and make product packaging more attractive and necessary for product development. On the other hand, the effect of market orientation on competitive advantage obtained positive but not significant results. This study also confirms that innovation can mediate the relationship between entrepreneurial insight and market orientation to competitive advantage. These results prove that process innovation is crucial to support entrepreneurial insight and market orientation to encourage sustainable competitive advantage. This study also confirms that innovation can mediate the relationship between entrepreneurial insight and market orientation to competitive advantage. These results prove that process innovation is crucial to support entrepreneurial insight and market orientation to encourage sustainable competitive advantage. This study also confirms that innovation can mediate the relationship between entrepreneurial insight and market orientation to competitive advantage. These results prove that process innovation is crucial to support entrepreneurial insight and market orientation to encourage sustainable competitive advantage.

\section{SUGGESTION}

According to the survey results in the field, there are still some business actors who do not fully have qualified entrepreneurial insight. It is important to conduct socialization by local governments regarding how to develop a creative and innovative entrepreneurial spirit. Then, the weakness of the current market orientation lies in the entrepreneurial focus of every business actor in considering broader aspects to generate profits, ranging from market needs, business operations to the competitive map. On the other hand, the inability of business actors to ensure the products they offer profitably satisfy customers. In addition, special training is needed for business actors to produce the latest product innovations to survive in the market share.

\section{ACKNOWLEDGEMENT}

On this occasion, the writing team would like to express their deepest gratitude to the DRPM for the funding budget for the National Competitive Research Scheme for Beginner Lecturer Research in 2021. The writing team would also like to express their deepest gratitude to all parties involved in the research completion process. and writing of articles, to the Regional Planning and Management Agency (BAPPEDA) of Pematangsiantar City which has provided a research permit, the entire academic community of the Sultan Agung College of Economics and to the editorial team and reviewers of management and business journals managed by the Indragiri Rengat School of Economics which always provide constructive input to improve this article.

\section{REFERENCES}

Afwa, A., Djajasinga, N. D., Sudirman, A., Sari, A. L., \& Adnan, N. M. (2021). Raising the Tourism Industry as an Economic Driver. Proceedings of the 2nd Annual Conference on Blended Learning, Educational Technology and Innovation (ACBLETI 2020) Raising, 560(Acbleti 2020), $118-123$.

Anning-Dorson, T. (2018). Innovation And Competitive Advantage Creation: The Role Of Organisational Leadership In Service Firms From Emerging Markets. International Marketing Review, 35(4), 580-600. https://doi.org/10.1108/IMR-11-2015-0262

Arsawan, I. W. E., Koval, V., Rajiani, I., Rustiarini, N. W., Supartha, W. G., \& Suryantini, N. P. S. (2020). Leveraging Knowledge Sharing And Innovation Culture Into Smes Sustainable 
Competitive Advantage. International Journal of Productivity and Performance Management, 1(1), 1-24. https://doi.org/10.1108/IJPPM-04-2020-0192

Arzubiaga, U., Kotlar, J., De Massis, A., Maseda, A., \& Iturralde, T. (2018). Entrepreneurial Orientation and Innovation in Family SMES: Unveiling The (Actual) Impact of The Board of Directors. Journal of Business Venturing, 33(4), 455-469. https://doi.org/10.1016/j.jbusvent.2018.03.002

Ayesha, I., Redjeki, F., Sudirman, A., Leonardo, A., \& Aslam, D. F. (2021). Behavior of Female Entrepreneurs in Tempe Small Micro Enterprises in Tasikmalaya Regency, West Java as Proof of Gender Equality Against AEC. Proceedings of the 2nd Annual Conference on Blended Learning, Educational Technology and Innovation (ACBLETI 2020), 560(Acbleti 2020), 124130.

Aziz, N. N. A., \& Samad, S. (2016). Innovation and Competitive Advantage: Moderating Effects of Firm Age in Foods Manufacturing SMEs in Malaysia. Procedia Economics and Finance, 35(October 2015), 256-266. https://doi.org/10.1016/s2212-5671(16)00032-0

Bambang, A., Kusumawati, A., Nimran, U., \& Suharyono, S. (2021). The Effect of Spiritual Marketing and Entrepreneurship Orientation on Determining Sustainable Competitive Advantage. Journal of Asian Finance, Economics and Business, 8(2), 231-241.

Distanont, A., \& Khongmalai, O. (2020). The Role of Innovation in Creating a Competitive Advantage. Kasetsart Journal of Social Sciences, 41(1), 15-21. https://doi.org/10.1016/j.kjss.2018.07.009

Djajasinga, N. D., Sulastri, L., Sudirman, A., Sari, A. L., \& Rihardi, L. (2021). Practices in Human Resources and Employee Turnover in the Hospitality Industry. Proceedings of the 2nd Annual Conference on Blended Learning, Educational Technology and Innovation (ACBLETI 2020) Practices, 560(Acbleti 2020), 113-117.

Fajrillah, Purba, S., Sirait, S., Sudarso, A., Sugianto, Sudirman, A., Febrianty, Hasibuan, A., Julyanthry, \& Simarmata, J. (2020). Smart Entrepreneurship: Peluang Bisnis Kreatif \& Inovatif di Era Digital (Cetakan 1). Yayasan Kita Menulis.

Hair, J. F. (2014). Multivariat Data Analysis 7th Edition. Pearson Prentice Hall.

Harjadi, D., Fatmasari, D., \& Nurhasanah, A. S. (2020). Market Orientation And Product Innovation To Increase Competitive Advantages And Its Impact On Marketing Performance. Al-Amwal : Jurnal Ekonomi Dan Perbankan Syari'ah, 12(1), 12. https://doi.org/10.24235/amwal.v1i1.5457

Harvey, M., Kiessling, T., \& Moeller, M. (2010). A View Of Entrepreneurship And Innovation From The Economist "For All Seasons." Journal of Management History, 16(4), 527-531. https://doi.org/10.1108/17511341011074004

Juliandi, A. (2018). Structural Equation Model Based Partial Least Square (SEM-PLS): Menggunakan SmartPLS. https://zenodo.org/record/2538001\#.X-YIiFUzbIU

Kiki, Z., Rusdarti, \& Sakitri, W. (2020). Pengaruh Orientasi Pasar, Orientasi Kewirausahaan dan Inovasi Produk Terhadap Kinerja Pemasaaran UKM. Business and Accounting Education Journal, 1(1), 27-42.

Lee, J., Kim, D., \& Sung, S. (2019). The Effect of Entrepreneurship on Start-Up Open Innovation: Innovative Behavior of University Students. Journal of Open Innovation: Technology, Market, and Complexity, 5(4), 1-13. https://doi.org/10.3390/joitmc5040103

Lee, T., \& Chu, W. (2011). Entrepreneurial Orientation and Competitive Advantage: The Mediation of Resource Value And Rareness. African Journal of Business Management, 5(33), 12797-12809. https://doi.org/10.5897/AJBM11.1179

Lestari, I., Astuti, M., \& Ridwan, H. (2019). Pengaruh Inovasi dan Orientasi Kewirausaahaan Terhadap Keunggulan Bersaing UMKM Kuliner. Jurnal Riset Manajemen Dan Bisnis, 4(1), 111-118.

Limaj, E., \& Bernroider, E. W. N. (2019). The Roles of Absorptive Capacity and Cultural Balance for Exploratory and Exploitative Innovation in SMEs. Journal of Business Research, 94(October 2017), 137-153. https://doi.org/10.1016/j.jbusres.2017.10.052

Meylananda, S., Sarkum, S., \& Halim, A. (2021). Analysis Market Orientation and Knowledge 
Management to Improve Innovation and Business Performance. Budapest International Research and Critics Institute-Journal, 4(3), 4241-4255.

Nurdin, F., Ihsan, M., Rahmawati, I., \& Lestari, H. (2020). Pengaruh Kepemimpinan Transformasional dan Budaya Organisasi Terhadap Perilaku Kerja Inovatif Guru Di SMA Swasta Se-Kecamatan Pamijahan Bogor. Indonesian Journal of Science, 1(2), 99-105. http://journal.pusatsains.com/index.php/jsi

Pratiwi, N. W. A., \& Riana, I. G. (2021). Entrepreneurial Orientation, Market Orientation on Silversmiths Innovation. Journal of Multidisciplinary Academic, 5(2), 124-128. http://www.kemalapublisher.com/index.php/JoMA/article/view/559

Purnomo, A., Sudirman, A., Abdurrozzaq, H., Sudarso, A., Sahir, H. S., Salmiah, Mastuti, R., Chamidah, D., Koryati, T., \& Simarmata, J. (2020). Dasar-Dasar Kewirausahaan: Untuk Perguruan Tingi dan Dunia Bisnis (Cetakan 1). Yayasan Kita Menulis.

Puspaningrum, A. (2017). The Effect of Market Orientation And Innovation on Competitive Advantages. Research Journal of Business and Management, 4(4), 549-558. https://doi.org/10.17261/pressacademia.2017.761

Santhi, N. H., \& Affandi, Y. (2020). Pengaruh Orientasi Kewirausahaan Dan Inovasi Produk Terhadap Kinerja Usaha Kecil Menengah (Ukm) (Studi Kasus Pada UKM Tenun Di Kecamatan Pringgasela Kabupaten Lombok Timur). JPEK (Jurnal Pendidikan Ekonomi Dan Kewirausahaan), 4(1), 52-65. https://doi.org/10.29408/jpek.v4i1.2112

Sarwono, J. (2016). Membuat Skripsi, Tesis dan Disertasi dengan Partial Least Square SEM (PLS SEM). Andi Offset.

Setyanti, S. W. L., Troena, E. A., Nimran, U., \& Rahayu, M. (2013). Innovation Role in Mediating the Effect of Entrepreneurship Orientation, Management Capabilities and Knowledge Sharing Toward Business Performance: Study at Batik SMEs in East Java Indonesia. Journal of Business and Management, 8(4), 16-27.

Sudirman, A., Halim, F., Nainggolan, A. B., Butarbutar, N., \& Sherly, S. (2021). Meninjau Hubungan Antara Penggunaan Media Sosial dan Orientasi Pasar Terhadap Kinerja Bisnis Sektor UMKM. Prosiding Seminar Nasional Ekonomi Dan Bisnis 2021 Universitas Muhammadiyah Jember, 165-179. https://doi.org/10.32528/psneb.v0i0.5165

Sultan, S., Rianda, L., \& Herdhiansyah, D. (2020). The Influence of Market Orientation on Product Innovation in The Palm Sugar Industry in The Watchunu Sub-District and North Poleang Bombana District. Tekper: Jurnal Teknologi Dan Manajemen Industri Pertanian, 1(1), 21. https://doi.org/10.33772/tekper.v1i1.11663

Sutapa, S., Mulyana, M., \& Wasitowati, W. (2017). The Role of Market Orientation, Creativity and Innovation in Creating Competitive Advantages and Creative Industry Performance. Jurnal Dinamika Manajemen, 8(2), 152-166. https://doi.org/10.15294/jdm.v1i1.12756

Udriyah, Tham, J., \& Ferdous Azam, S. M. (2019). The Effects Of Market Orientation And Innovation On Competitive Advantage And Business Performance Of Textile Smes. Management Science Letters, 9(9), 1419-1428. https://doi.org/10.5267/j.msl.2019.5.009

Yaskun, M., \& Sudarmiatin. (2021). The Role of Entrepreneurship Orientation and Market Orientation on Product Innovation and Business Performance at SMEs Restaurants in Lamongan. Enrichment: $\quad$ Journal of Management, 11(2), 360-365. https://www.enrichment.iocspublisher.org/index.php/enrichment/article/view/105

Zainol, N. R., \& Al Mamun, A. (2018). Entrepreneurial Competency, Competitive Advantage And Performance of Informal Women Micro-Entrepreneurs in Kelantan, Malaysia. Journal of Enterprising Communities, 12(3), 299-321. https://doi.org/10.1108/JEC-11-2017-0090 